\title{
AUTISMIKIRJON OSAMÄÄRÄ (AQ) AUTISMIKIRJON PIIRTEITÄ SEULOMASSA: SEULONTALOMAKKEEN EROTTELUKYKY NUORILLA AIKUISILLA
}

Soile Loukusa, Logopedian tutkimusyksikkö, Oulun yliopisto

Aija Kotila, Logopedian tutkimusyksikkö, Oulun yliopisto

Marja-Leena Mattila, PEDEGO-tutkimusyksikkö, Lääketieteellinen tiedekunta, Oulun yliopisto ja Lastenpsykiatrian vastuualue, Oulun yliopistollinen sairaala

Maija Ylämäki, Etelä-Karjalan sosiaali- ja terveyspiiri (Eksote)

Leena Joskitt, Lastenpsykiatrian vastuualue, Oulun yliopistollinen sairaala ja PEDEGO-tutkimusyksikkö, Oulun yliopisto

Irma Moilanen, Lastenpsykiatrian vastuualue, Oulun yliopistollinen sairaala ja PEDEGO-tutkimusyksikkö, Oulun yliopisto

Hanna Ebeling, PEDEGO-tutkimusyksikkö, Lääketieteellinen tiedekunta, Oulun yliopisto ja Lastenpsykiatrian vastuualue, Oulun yliopistollinen sairaala

Tuula Hurtig, Neurotieteen tutkimusyksikkö, PEDEGOtutkimusyksikkö, Oulun yliopisto ja Lastenpsykiatrian vastuualue, Oulun yliopistollinen sairaala 
Autismikirjon piirteet ulottuvat sosiaalisten taitojen, kommunikaation, mielikuvituksen, tarkkaavuuden siirtämisen ja yksityiskohtien huomioimisen alueille. Näillä osa-alueilla esiintyviä piirteitä voidaan seuloa autismikirjon osamäärän (engl. autism spectrum quotient, $A Q$ ) avulla. Tämän tutkimuksen tavoitteena on saada suomalaiset viitearvot AQ:Ile sekä tarkastella, erotteleeko AQ-lomake suomalaisia autismikirjon nuoria aikuisia oman sukupuolen nuorista aikuisista, joilla ei ole autismikirjon diagnoosia. Lisäksi tarkastellaan ryhmien suoriutumisessa olevia eroja osioittain sekä AQ:n sisäistä yhtenäisyyttä. Tutkimukseen osallistui 52 autismikirjon nuorta aikuista (39 miestä ja 13 naista) sekä 1686 verrokkia (577 miestä ja 1109 naista). Tulokset osoittavat, että autismikirjon henkilöiden pistemäärät nousevat samaa sukupuolta olevien verrokkihenkilöiden pistemääriä korkeammalle. $\mathrm{AQ}$ erottelee autismikirjon miehet melko hyvin verrokkimiehistä, mutta autismikirjon naiset vain kohtalaisesti verrokkinaisista. Osioanalyysissä eniten ryhmien välisiä tilastollisesti merkitseviä eroja tuli esille sosiaalisia taitoja ja kommunikaatiota mittaavissa väittämissä.

Avainsanat: autismikirjo, AQ, kommunikaatio, seulonta, sosiaaliset taidot, tarkkaavaisuuden siirtäminen, yksityiskohtien huomioiminen

\section{JOHDANTO}

Autismikirjon häiriö on käyttäytymispiirteiden perusteella diagnosoitava kehityksellinen häiriö (American Psychiatric Association, APA, 2013, DSM-5; World Health Organization, WHO, 2018, ICD-11). Aikaisempi suomalainen autismikirjon piirteitä kartoittava tutkimus on pääasiassa keskittynyt lapsiin (esim. Mattila ym., 2012), ja ainakin osittain tästä syystä autismikirjon henkilöiden itsearviointia ei ole juurikaan käytetty suomalaisessa tutkimuksessa. Autismikirjossa keskeisen oirekuvan muodostavat 1) sosiaalisen vuorovaikutuksen ja kommunikointikyvyn poikkeavuudet sekä 2) toistava käyttäytyminen, rajoittuneet kiinnostuksen kohteet sekä aistipoikkeavuudet (DSM-5; ICD-11).

Kommunikointikyvyn osalta autismikirjon henkilöt ovat hyvin heterogeeninen ryhmä, sillä noin $30 \%$ :lla autismikirjon henkilöistä puhekieli ei yllä lausetasolle (Tager-Flusberg
\& Kasari, 2013), kun taas toisten kieli on muodoltaan jopa ylihuoliteltua, ja heidän kommunikointivaikeutensa näkyvät lähinnä sosiaalisessa kommunikoinnissa. Vaikka kehitysvammaisten osuus autismikirjon häiriössä on laskenut, se on edelleen liitännäisvammana noin 32-48 \%:lla autismikirjon henkilöistä (The Developmental Disabilities Monitoring Network Surveillance, 2014; Mattila ym., 2011; Postorino ym., 2016). Tämä tutkimus käsittelee autismikirjon henkilöitä, jotka kommunikoivat puheella ja joilla ei ole kehitysvammaa. Näin ollen tämän tutkimuksen koehenkilöjoukko ei edusta koko autismikirjoa, vaan älykkyydeltään tyypillisen tason rajoissa (tai sen yli) toimivien ja puhuvien autismikirjon henkilöiden ryhmää. Aikaisemmat tutkimukset ovat osoittaneet, että autismikirjon henkilöiden vaikeudet tehdä tilanteen kannalta sopivia päätelmiä näkyvät 
sosiaalisessa kommunikaatiossa (Loukusa \& Moilanen, 2009). Lisäksi autismikirjon henkilöt voivat jatkaa prosessointia vielä oikeaan päätelmään pääsemisen jälkeen, mikä lopulta johtaa aiheesta poikkeamiseen (Loukusa ym., 2007). Tilannesidonnaisen kielen ymmärtämisen vaikeudet näkyvät autismikirjon henkilöiden epäsuoran kielen kuten huumorin (Emerich, Creaghead, Grether, Murray \& Grasha, 2003) ja ironian (Deliens, Papastamou, Ruytenbeek, Geelhand de Merxem, \& Kissine, 2018; Wang, Lee, Sigman \& Dapretto, 2006) ymmärtämisessä. Keskustelutaitoja heikentävät epäolennaisen tiedon esille tuominen, aiheen vaihtaminen, kommunikatiivisen katseen käytön vaikeudet ja prosodiset poikkeavuudet (Paul, Orlovski, Marcinko \& Volkmar, 2009; Sng, Carter \& Stephenson, 2018). Sosiaalista kommunikaatiota vaikeuttavat myös autismikirjoon liittyvät tunnetilojen tunnistamisen vaikeudet, sillä esimerkiksi tunteiden tunnistaminen kasvojen ilmeistä voi olla haastavaa (Loukusa, Mäkinen, Kuusikko-Gauffin, Ebeling \& Moilanen, 2014).

Autismikirjon henkilöiden käyttäytymismalleissa voidaan nähdä kolmenlaista suuntautumista: tarve samankaltaisuuteen, tarve toteuttaa toistavaa käyttäytymistä ja tarve keskittää huomio rajoittuneisiin mielenkiinnon kohteisiin (Lam, Bodfish \& Piven, 2008). Bishopin ym. (2013) mukaan stereotypiat esiintyvät usein sensomotorisena ja rituaalinomaisena käyttäytymisenä. Lisäksi voi esiintyä itseä vahingoittavaa käyttäytymistä. Aistipoikkeavuudet voivat olla yli- tai alireagoimista, ja ne voivat liittyä eri aistialueille (esim. kuulo-, näkö- ja tuntoaisti). Jussilan ym. (2019) tutkimuksessa todettiin, että erityisesti tunto- ja kuuloaistin yliherkkyys ennustavat autismikirjon diagnoosia. Lisäksi on havaittu, että aistiherkkyys voi olla lapsen ensimmäiseksi huomattu autismikirjon piirre, jonka avulla voidaan jopa selittää ja ennustaa myöhempiä sosiaalisen kommunikaation vaikeuksia (Ro- bertson \& Baron-Cohen, 2017). Oirekuvaa katsottaessa on myös syytä huomioida, että vaikka rajoittuneet kiinnostuksen kohteet ja aistipoikkeavuudet voidaan erottaa sosiaalisesta kommunikaatiosta, myös niillä on vaikutusta henkilön sosiaaliseen kommunikaatioon. Näin ollen autismikirjon henkilön piirteitä tulisikin arvioida kokonaisuutena ja samalla huomioida se, miten eri piirteet ovat yhteydessä ja vaikuttavat toisiinsa. Esimerkiksi koulun tai ostoskeskuksen äänimaailma voi olla kuuloaistiltaan yliherkälle henkilölle epämiellyttävä ja voi näin ollen heikentää hänen kykyään kommunikoida ja oppia sosiaalista viestintää näissä tilanteissa (ks. myös Loukusa, painossa).

Epäiltäessä autismikirjon häiriötä lapsen autismikirjon piirteitä kartoitetaan moniammatillisesti testaamalla, havainnoimalla sekä vanhempia ja lapsen lähipiiriä haastattelemalla. Aikuisiässä diagnosointi tapahtuu testien ja havainnoinnin lisäksi henkilöä itseään sekä hänen lapsuusaikaisen käyttäytymisensä hyvin tuntevaa henkilöä haastattelemalla. Tarpeen mukaan voidaan hyödyntää myös erilaisia itsearviointimenetelmiä kuten autismikirjon osamäärä (AQ, Autism Spectrum Quotient, Baron-Cohen, Wheelwright, Skinner, Martin \& Clubley, 2001), empatiaosamäärä (EQ, Empathizing Quotient, Baron-Cohen, \& Wheelwright, 2004) ja systemointiosamäärä (SQ, Systemizing Quotient, Baron-Cohen, Richler, Bisarya, Gurunathan, \& Wheelwright, 2003). Itsearviointimenetelmät nostavat esille henkilön itsessään havainnoimia vahvuuksia ja heikkouksia. Kliinisessä työssä itsearviointimenetelmiä käytetään usein seulottaessa henkilöitä, jotka ovat mahdollisesti tarkempien diagnostisten tutkimusten tarpeessa. On hyvä huomata, että henkilöt, joilla on lievä autismikirjon häiriö, ja muu aikuisväestö eroavat toisistaan vain vähän itsearviointimenetelmillä saaduissa tuloksissa. Lisäksi samanlaisia oireita voi esiintyä myös 
muissa psykiatrisissa häiriöissä (South, Carr, Stephenson, Maisel \& Cox, 2017). Itsearviointimenetelmien tulosten luotettavuuteen voivat vaikuttaa myös vastaajan itsetuntemus sekä mahdollinen halu tarjota tietyntyyppisiä sosiaalisesti sopiviksi opittuja vastauksia. Näin ollen AQ:n tapaisten itsearviointien tulisikin mieluummin toimia seulana kuin kliinisten johtopäätösten tekemisen lähteenä.

Lisäksi on huomioitava, että Suomessa käytössä olevien itsearviointimenetelmien viitearvot pohjaavat usein englannin kieltä puhuvien eri kulttuureista tulevien henkilöiden vastauksiin. Kuitenkin tiedetään, että myös länsimaisissa kulttuureissa on eroja esimerkiksi sosiaalisen kommunikaation tavoissa ja taidoissa (esim. Huttunen \& Pine, 2012; Gabbatore ym., 2019; Mäkinen, Gabbatore, Loukusa, Kunnari \& Schneider, 2019). Lisäksi tiedetään, että myös lapsilla käytettävän Autismikirjon seulontalomakkeen (ASSQ) rajapisteet vaihtelevat eri maiden ja kulttuurien välillä (Ehlers, Gillberg \& Wing, 1999; Guo ym., 2011; Mattila ym., 2012; Posserud, Lundervold \& Gillberg, 2009). Tämän takia olisi erittäin tärkeää, että arviointimenetelmien tulosten tulkinnassa apuna käytettävät viitearvot pohjautuisivat suomalaispopulaation tutkimuksiin. Yleensä viitearvot kertovat testin keskiarvon ja keskihajonnan kyseisessä populaatiossa. Onkin ilmeistä, että tällä hetkellä tarvitaan lisätutkimusta siitä, minkälaisia vastauksia autisminkirjon piirteitä kartoittaviin kysymyksiin antavat niin tyypillistä aikuisväestöä kuin autismikirjoa edustavat henkilöt. Autismikirjoon liittyvää oirekuvaa on pyritty selittämään pääasiassa mielen teorian (BaronCohen, Leslie \& Frith, 1985), sentraalisen koherenssiteorian (Frith, 1989), eksekutiivisen teorian (Hill, 2004) ja empatointi-systemointi-teorian (Empathizing-Systemizing Theory, E-S-teoria; Baron-Cohen, 2009) avulla. E-S-teorian mukaan autismikirjon henkilöiden empatiataidot ovat keskimää- räistä alhaisempia ja systemointitaidot ovat puolestaan keskimääräistä vahvemmat. Teoria ehdottaakin, että autismioireiden taustalla on näiden taitojen välinen epäsuhta.

AQ on seulontamenetelmä, jonka kehitystyön lähtökohtana on ollut tarve saada käyttöön nopea ja yksinkertainen seulontalomake, jolla pystyttäisiin kartoittamaan autismikirjon oirepiirteitä aikuisilta, joilla ei ole kehitysvammaa liitännäisvammana (BaronCohen ym., 2001). AQ:n toimivuutta on tutkittu runsaasti, ja autismikirjon henkilöt ovat saaneet siinä keskimäärin korkeampia pisteitä kuin muu aikuisväestö (mm. BaronCohen ym., 2001; Hoekstra, Bartels, Cath \& Boomsma, 2008; Ketelaars ym., 2008; Lundqvist \& Lindner, 2017). Ketelaarsin ym. (2008) tutkimuksessa on kuitenkin myös havaittu, että aikuisilla, joilla on lievä autismikirjon häiriö, pisteet eivät eroa merkitsevästi tyypillistä aikuisväestöä edustavien aikuisten pistemääristä. Myös sukupuolten välisiä eroja on havaittu, ja yleisesti miehet ovat saaneet naisia korkeammat pisteet sekä autismikirjon ryhmässä että tyypillisessä väestössä (esim. Baron-Cohen ym., 2001; Baron-Cohen, Hoekstra, Knickmeyer \& Wheelwright, 2006).

Tämän tutkimuksen tavoitteena on 1) saada suomalaiset viitearvot (keskiarvo ja keskihajonta) AQ:lle sekä AQ:n eri osaalueille (sosiaaliset taidot, kommunikaatio, mielikuvitus, tarkkaavuuden siirtäminen ja yksityiskohtien huomioiminen). Tämän jälkeen tarkastellaan 2) erotteleeko AQlomake suomalaisia autismikirjon nuoria aikuisia henkilöistä, jolla ei ole autismikirjon häiriön diagnoosia (verrokit). Tarkastelu tehdään vertaamalla samaa sukupuolta olevia ryhmiä keskenään (autismikirjon naiset ja verrokkinaiset sekä autismikirjon miehet ja verrokkimiehet). Tämän jälkeen tarkastellaan 3) ryhmien suoriutumisessa olevia eroja osioittain (yksittäiset väittämät), jotta voidaan 
havaita, missä osioissa erot ovat suurimmat ja mitkä kysymykset eivät puolestaan tuo esille eroja suomalaisväestössä. Koska AQ:ta ei ole tässä laajuudessa käytetty aikaisemmin suomalaistutkimuksessa, lopuksi 4) tarkastellaan mittarin sisäistä yhtenäisyyttä, jotta saadaan lisätietoa $A Q: n$ toimivuudesta suomalaisten henkilöiden arvioinnissa.

\section{MENETELMÄT}

\subsection{Koebenkilöt}

Tutkimusaineisto on osa Oulun yliopistollisen sairaalan (OYS) lastenpsykiatrian vastuualueella toteutettavaa nuorten aikuisten elämäntilannetta ja hyvinvointia koskevaa seurantatutkimusta, jossa kartoitetaan myös autismikirjon ilmiasua lapsuudesta aikuisuuteen (ks. https://www.oulu.fi/autismresearch/node/43868). Tutkimukseen on saatu lausunto Pohjois-Pohjanmaan sairaanhoitopiirin alueelliselta eettiseltä toimikunnalta. Autismikirjon ryhmään kuuluvat henkilöt on diagnosoitu ICD-10 kriteeristön mukaan lapsuudessa tai nuoruudessa OYS:ssa osana aikaisempaa autismikirjon tutkimusta (esim. Kuusikko ym., 2009; Mattila ym., 2011) tai heidät on rekrytoitu kliinisestä potilasaineistosta osaksi seurantatutkimusta. Tässä tutkimuksessa autismikirjon henkilöitä $(n=90)$ ja tyypillistä aikuisväestöä edustavia henkilöitä ( $\mathrm{n}=4247)$ on lähestytty uudelleen kirjeitse, ja osana muuta tutkimusta heitä on pyydetty täyttämään AQ-lomake sähköisessä muodossa Webropol-palvelussa. Henkilöille, jotka ei-

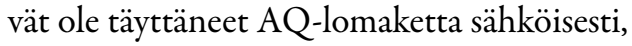
on lähetetty myöhemmin lomake kirjallisena postin kautta. Tutkimuksen vastausprosentti autismikirjon henkilöiden osalta on $63 \%$ ja tyypillistä aikuisväestöä edustavien henkilöiden osalta $41 \%$. Tyypillistä aikuisväestöä edustavista henkilöistä käytetään jatkossa myös termiä verrokit.
Tätä tutkimusta varten koko aineistosta on poistettu yhteensä kahdeksan henkilöä kehitysvammadiagnoosin vuoksi, koska $\mathrm{AQ}$ on tarkoitettu henkilöille, joiden älykkyys on tyypillisen rajoissa tai sen yli. Aineistossa on yhteensä 52 autismikirjon henkilöä ja 1686 verrokkia (taulukko 1). Kokonaispistemääriä koskevista tuloksista jätettiin pois kolmen autismikirjon ryhmään kuuluvan miehen sekä 35 verrokin (10 miestä ja 25 naista) tulokset, koska heiltä puuttui osa vastauksista. He ovat kuitenkin mukana osioita koskevissa tuloksissa niissä osioissa, joihin he ovat vastanneet. 
TAULUKKO 1. Tutkimukseen osallistuvien lukumäärä, sukupuoli ja ikä autismikirjon ryhmässä ja verrokkiryhmässä

\begin{tabular}{|c|c|c|}
\hline & $\begin{array}{l}\text { Autismikirjon } \\
\text { ryhmä }\end{array}$ & Verrokkiryhmä \\
\hline $\mathbf{N}$ & 52 & 1686 \\
\hline miehet & 39 & 577 \\
\hline naiset & 13 & 1109 \\
\hline \multicolumn{3}{|l|}{ Ikä (kaikki) } \\
\hline$k a(k h)$ & $21,9(3,2)$ & $21,0(0,5)$ \\
\hline$v v$ & $17,7-32,0$ & $17,9-29,2$ \\
\hline \multicolumn{3}{|l|}{ Ikä (miehet) } \\
\hline ka (kh) & $22,3(3,6)$ & $21,1(0,6)$ \\
\hline VV & $17,7-32,0$ & $18,5-29,2$ \\
\hline \multicolumn{3}{|l|}{ Ikä (naiset) } \\
\hline$k a(k h)$ & $20,7(3,2)$ & $21,0(0,4)$ \\
\hline vv & $18,3-23,7$ & $17,9-25,2$ \\
\hline
\end{tabular}

\subsection{Autismikirjon osamäärä (AQ)}

AQ on Baron-Cohenin ja hänen työryhmänsä (2001) kehittelemä autismioireita seulova lomake, johon kuuluu 50 väittämää viideltä eri osa-alueelta: sosiaaliset taidot (osiot 1, 11, $13,15,22,36,44,45,47,48)$, kommunikaatio (osiot 7, 17, 18, 26, 27, 31, 33, 35, 38, 39), mielikuvitus (osiot 3, 8, 14, 20, 21, 24, 40, 41, 42, 50), tarkkaavuuden siirtäminen (osiot 2 , $4,10,16,25,32,34,37,43,46)$ ja yksityiskohtien huomioiminen (osiot 5, 6, 9, 12, 19, 23, 28, 29, 30, 49). Vastatessaan väittämiin vastaajat ovat harkinneet niiden paikkaansa pitävyyttä omalla kohdallaan 4-portaisen Likert-asteikon avulla (täysin eri mieltä - melko eri mieltä - melko samaa mieltä - täysin samaa mieltä).

Jos henkilö on vastauksellaan ilmaisut lievän tai vahvan autismikirjon kaltaisen piirteen sopivan itseensä, hän saa väittämästä yhden pisteen. Puolessa osioista pisteen saamiseen vaaditaan positiivinen vastaus (samaa mieltä) ja puolessa osioissa puolestaan negatiivinen vastaus (eri mieltä). Maksimissaan väittämistä voi saada yhteensä 50 pistettä. Tutkimuksessa on käytetty Ulrika Roineen suomentamaa versiota. Suomenkielinen versio on vapaasti saatavilla tutkijoiden käyttöön Cambridgen yliopiston Simon Baron-Cohenin johtaman Autism Research Centerin internet-sivustolla (http://www.autismresearchcentre.com/ arc_tests). Kyseiseltä sivustolta löytyy myös englanninkielinen osioiden pisteytysohje. Suomalaisen AQ:n version käännös on tehty Roineen ja kumppaneiden tutkimuksia varten, ja käännösprosessiin on kuulunut takaisinkääntäminen väittämien alkuperäisten merkitysten varmentamiseksi (ks. Roine ym., 2013). 


\subsection{Aineiston analyysi}

Ryhmien tuloksia tarkastellaan aluksi keskilukuja vertaamalla ja hajontakuvioiden avulla. AQ:n toimivuutta autismikirjon henkilöiden erottelussa verrokeista tarkastellaan ROCkäyrän (receiver operating characteristic) avulla. ROC-käyrä ilmaisee y-akselilla sensitiivisyyden ja x-akselilla 1-spesifisyyden. Lisäksi katsotaan käyrän alle jäävän alueen pinta-alaa (AUC). AUC-arvot voidaan tulkita siten, että arvoilla 0,9-1 mittarin toimivuus on erinomainen, arvoilla $0,8-0,9$ toimivuus on hyvä, arvoilla $0,6-0,7$ toimivuus on kohtalainen, arvoilla $0,6-0,7$ toimivuus on heikohko, ja arvot välillä 0,5-0,6 kuvastavat mittarin toimimattomuutta (ks. El Khouli ym., 2009; Lüdemann, Grieger, Wurm, Wust \& Zimmer, 2005). ROC-käyrällä pyritään löytämään tässä aineistossa myös niin sanottu katkaisuraja (engl. cut off point) eli pistemäärä, joka erottaa tutkittavat ryhmät toisistaan parhaiten (Forsström, 1995). Tämä tarkoittaa sitä, että ROC-käyrän avulla pyritään löytämään pistemäärä, jossa on ryhmien erottelun kannalta paras sensitiivisyys ja spesifisyys, eli pistemäärä sijaitsee lähinnä alueen vasenta yläkulmaa. Mikäli ei ole mahdollista löytää yhtä, selvästi parasta pistemäärää sensitiivisyyden ja spesifisyyden kannalta, kuvataan useampia pistemääriä sekä niiden sensitiivisyys ja spesifisyys, jotta AQ:ta käyttävä tutkija tai asiantuntija voi valita tilanteen kannalta parhaan mahdollisen raja-arvon (halutaanko esimerkiksi, että AQ seuloo mahdollisimman tarkasti autismikirjon henkilöt, vaikka sitten seuloutuisi myös kohtuullisen paljon tyypillisesti toimivia joukkoon, vai toisinpäin niin, että seulaan eivät helposti jää tyypillisesti toimivat henkilöt, mutta myös moni autismikirjon henkilö jää havaitsematta).

Osioanalyysissä tarkastellaan sukupuolittain prosenttiosuuksilla sekä Khiin neliötestillä, missä väittämissä autismikirjon ja verrokkien ryhmät eroavat toisistaan. Koska osioanalyysi edellyttää lukuisia vertailuja (50 osiota), todennäköisyys saavuttaa tilastollisesti merkitsevä ero nousee. Siksi merkitsevyystasoa lasketaan alaspäin 0,001:een Bonferronin kertoimen avulla. Koska AQ:ta ei ole aikaisemmin tutkittu Suomessa näin laajalla aineistolla, lopuksi testin sisäistä reliabiliteettia arvioidaan Cronbachin alfa -kertoimien avulla. Hyvän alfa-kertoimen raja-arvona pidettiin Metsämuurosen (2006, s. 56-60) ehdottamaa 0,6 alfa-kerrointa.

\section{TULOKSET}

\subsection{Koehenkilöiden tulokset}

Kun tarkastellaan autismikirjon ja verrokkiryhmien AQ-testin kokonaispisteitä, havaitaan, että autismikirjon ryhmässä testiosaalueiden pisteet ovat kautta linjan korkeammat kuin verrokkiryhmässä (taulukko 2). Tarkasteltaessa keskiarvoja sukupuolittain on havaittavissa, että autismikirjon henkilöiden keskiarvot nousivat samaa sukupuolta olevien verrokkihenkilöiden keskiarvoja korkeammalle muuten paitsi yksityiskohtien huomioimisen osa-alueella, jossa autismikirjon naisten ja verrokkinaisten keskiarvot olivat lähes vastaavat. 
Taulukko 2. Autismikirjon henkilöiden ja verrokkihenkilöiden pisteet sukupuolittain autismikirjon osamäärän (AQ) osa-alueilla

\begin{tabular}{|c|c|c|c|c|c|c|}
\hline & $\begin{array}{l}\text { Sosiaaliset } \\
\text { taidot }\end{array}$ & $\begin{array}{l}\text { Kommuni- } \\
\text { kaatio }\end{array}$ & $\begin{array}{l}\text { Mieli- } \\
\text { kuvitus }\end{array}$ & $\begin{array}{l}\text { Tarkkaa- } \\
\text { vuuden } \\
\text { siirtäminen }\end{array}$ & $\begin{array}{l}\text { Yksityiskohtien } \\
\text { huomioiminen }\end{array}$ & AQ yht. \\
\hline \multicolumn{7}{|l|}{$\begin{array}{l}\text { Autismikirjon } \\
\text { ryhmä }\end{array}$} \\
\hline ka & 5,5 & 3,9 & 3,9 & 4,7 & 4,2 & 22,5 \\
\hline$k h$ & 2,8 & 2,5 & 2,0 & 2,0 & 1,9 & 8,3 \\
\hline \multicolumn{7}{|l|}{ miehet } \\
\hline ka & 5,8 & 3,8 & 3,8 & 4,7 & 4,3 & 22,7 \\
\hline$k h$ & 2,9 & 2,4 & 1,8 & 2,0 & 1,7 & 7,8 \\
\hline \multicolumn{7}{|l|}{ naiset } \\
\hline ka & 4,9 & 4,2 & 4,1 & 4,7 & 3,8 & 21,7 \\
\hline$k h$ & 2,7 & 3,0 & 2,6 & 2,2 & 2,6 & 9,9 \\
\hline \multicolumn{7}{|l|}{ Verrokkiryhmä } \\
\hline ka & 2,2 & 1,6 & 2,6 & 3,1 & 3,6 & 13,1 \\
\hline$k h$ & 2,2 & 1,8 & 1,8 & 2,1 & 2,2 & 6,4 \\
\hline \multicolumn{7}{|l|}{ miehet } \\
\hline ka & 2,3 & 1,7 & 3,2 & 3,3 & 3,5 & 14,1 \\
\hline$k h$ & 2,3 & 1,8 & 1,9 & 2,1 & 2,2 & 6,3 \\
\hline \multicolumn{7}{|l|}{ naiset } \\
\hline ka & 2,1 & 1,5 & 2,3 & 3,0 & 3,7 & 12,6 \\
\hline$k h$ & 2,2 & 1,7 & 1,7 & 2,1 & 2,2 & 6,3 \\
\hline
\end{tabular}

Kuvio 1 osoittaa, että vaikka ryhmien AQ:n pistemäärien jakaumat leikkaavat toisensa, jakaumien huiput sijoittuvat eri pistemäärien kohdalle. Koska ryhmät eivät olleet sukupuolen mukaan kaltaistettuja ja verrokkimiesten pisteet olivat korkeammat kuin verrokkinaisten $(\mathrm{U}=264882.0, \mathrm{p}<0.001)$, jatkossa tuloksia tarkastellaan sukupuolittain. Kuvioista 2 ja 3 havaitaan, että AQ:n kokonaispisteiden jakaumien huiput (prosentuaalinen osuus, yakseli) sijoittuvat verrokkimiehillä ja -naisilla alemmalle pistemäärälle ( $\mathrm{x}$-akseli) kuin autismikirjon miehillä ja naisilla. 


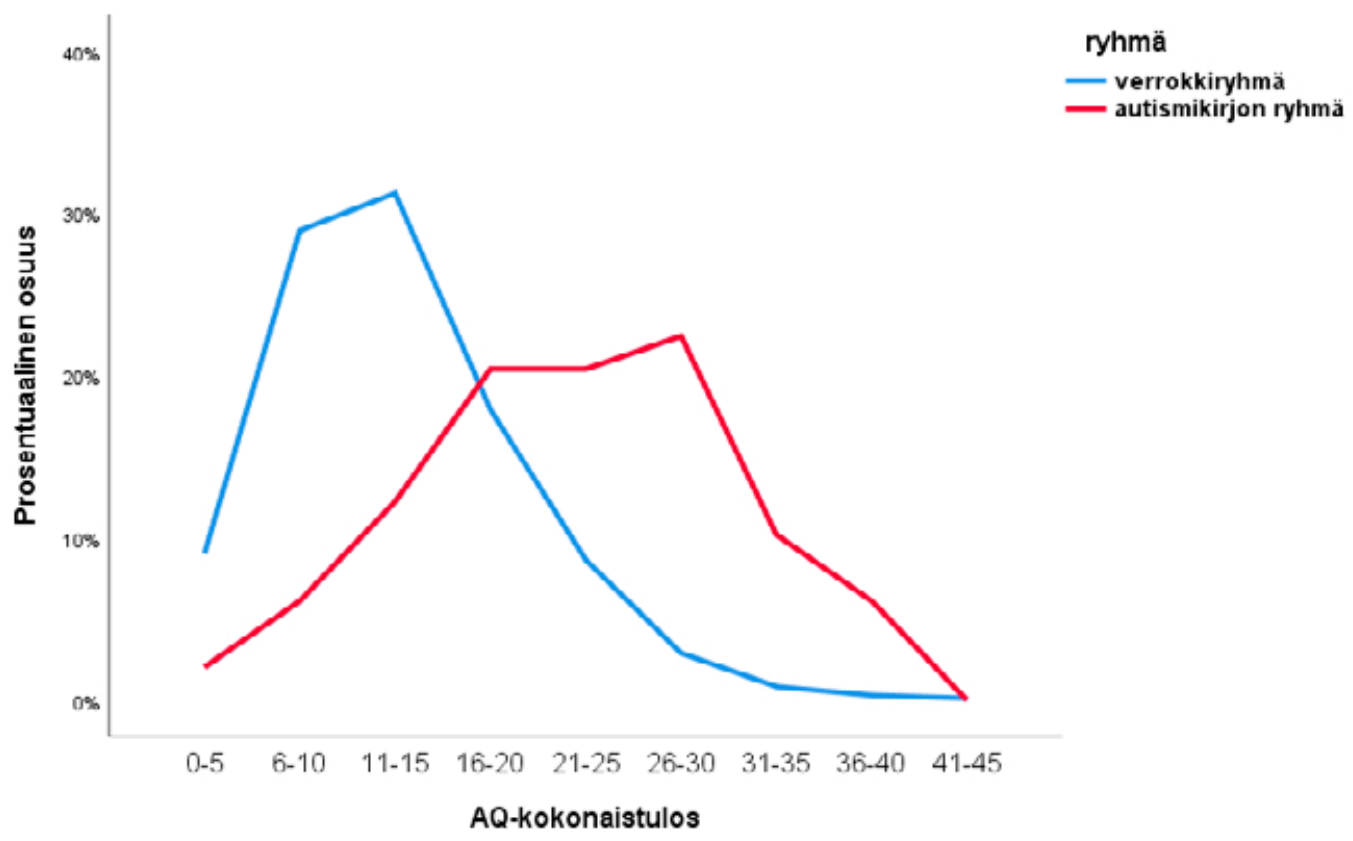

KUVIO 1. Autismikirjon osamäärän (AQ) kokonaistulos ryhmittäin.

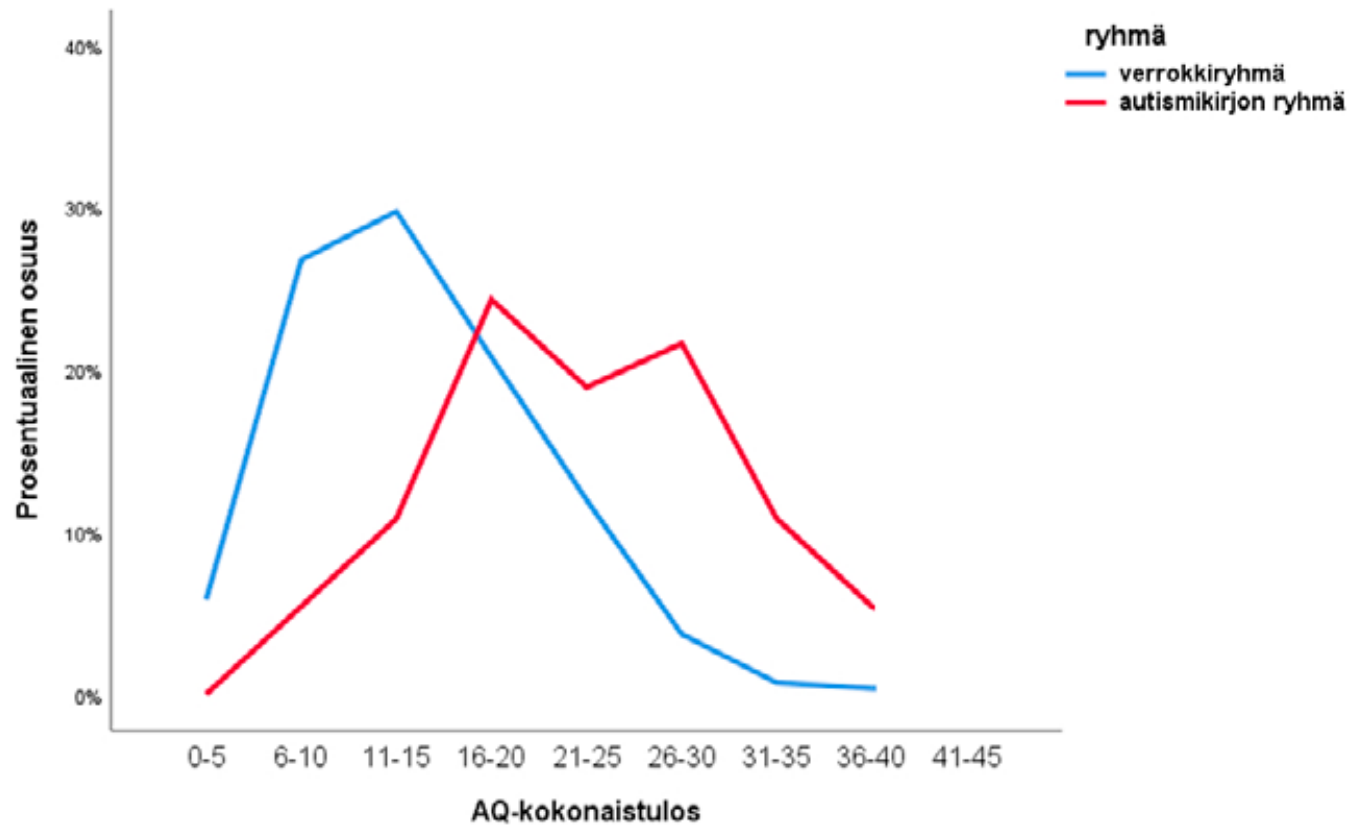

KUVIO 2. Autismikirjon osamäärän (AQ) kokonaistulos miehillä. 


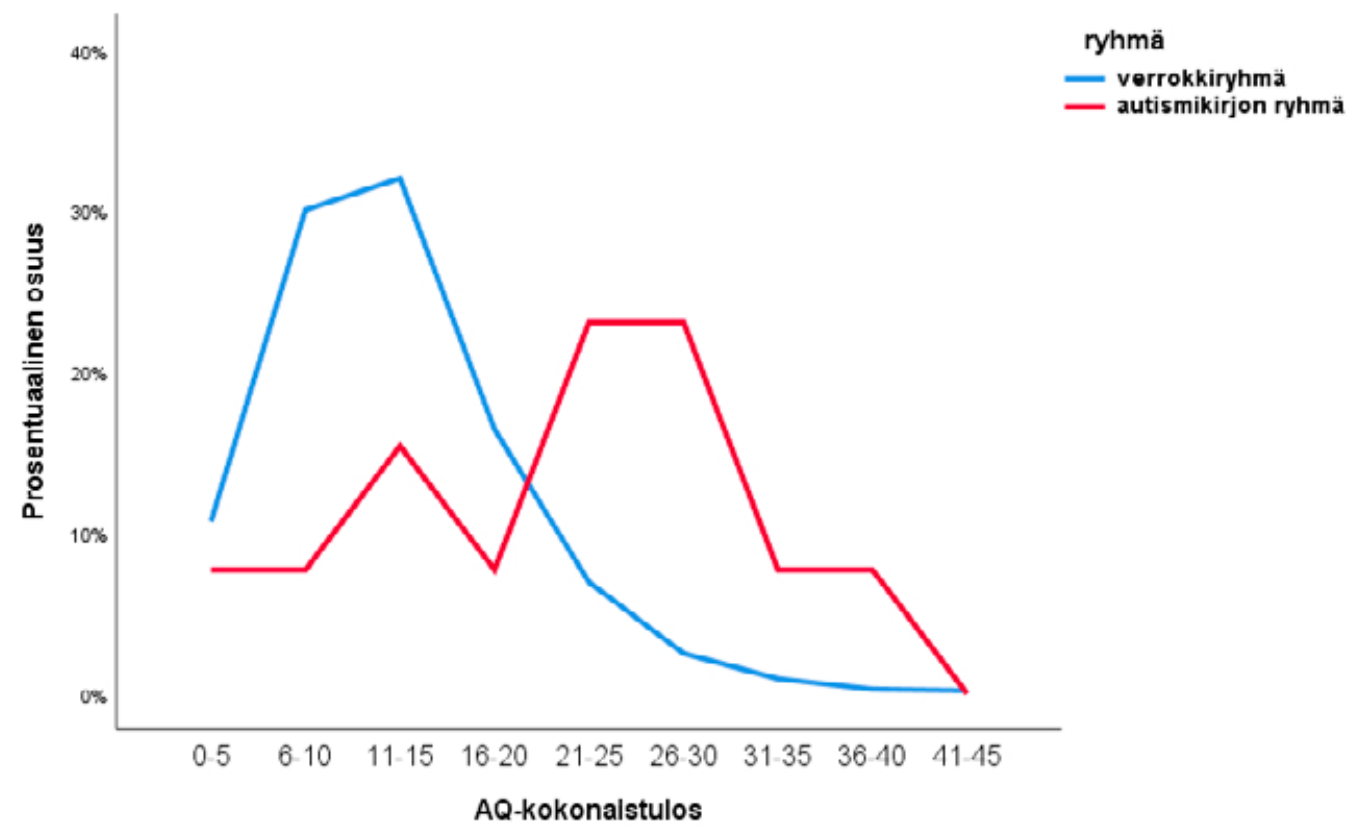

KUVIO 3. Autismikirjon osamäärän (AQ) kokonaistulos naisilla.

\subsection{Autismikirjon osamäärän} erottelukyky sukupuolittain tarkasteltuna

Positiivinen ja ylöspäin kupera ROC-käyrä osoittaa, että AQ erottelee autismikirjon miesten ja verrokkimiesten ryhmät toisistaan (Kuvio 4, $A U C=0,803, p<0,001$, 95 \% luottamusväli $0,726-0,879)$. Vaikka ROC-käyrän mukaan $\mathrm{AQ}$ näyttäisi erottelevan autismikirjon miehet verrokeista melko hyvin, selkeää katkaisurajapistettä on vaikea märrittää. Mikäli katkaisuraja sijoitetaan 18 pisteen kohdalle, mittarin sensitiivisyys on 73 $\%$ ja spesifisyys $76 \%$. Katkaisurajapisteellä 15 päästään $83 \%$ :n sensitiivisyyteen, mutta spesifisyys on silloin vain $62 \%$. Taulukossa 3 on esitetty autismikirjon miesten ja verrokkimiesten pisteiden jakautuminen eri AQpistemäärien ylä- ja alapuolelle. 


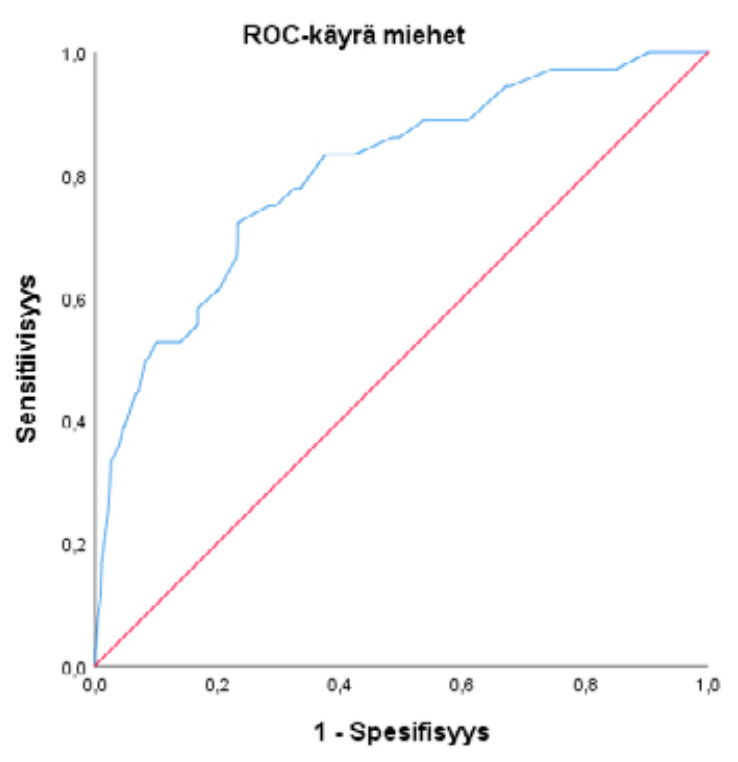

KUVIO 4. Autismikirjon osamäärän (AQ) kyky erotella (sensitiivisyys ja spesifisyys) autismikirjon miehet verrokkimiehistä.
AQ erottelee autismikirjon naiset verrokkinaisista vain kohtalaisen hyvin (kuvio 5, $A U C=0,771, p=0,001,95$ $\%$ luottamusväli 0,614-0,928). Naisten kohdalla on erityisten vaikea määrittää selkeää katkaisurajaa, jossa olisi riittävän hyvä sensitiivisyys ja spesifisyys. Mikäli autismikirjon ja verrokkinaisten AQ:n katkaisurajaksi asetetaan 16 pistettä, on sensitiivisyys $73 \%$ ja spesifisyys 70 $\%$. Pisterajalla 13 saadaan sensitiivisyys nostettua $77 \%$ :iin, mutta tällöin spesifisyys jää alhaiseksi $62 \%$ :iin. Taulukosta 3 nähdään, miten autismikirjon naisten ja verrokkinaisten pisteet jakautuvat eri AQ-pisteiden ylä- ja alapuolelle.

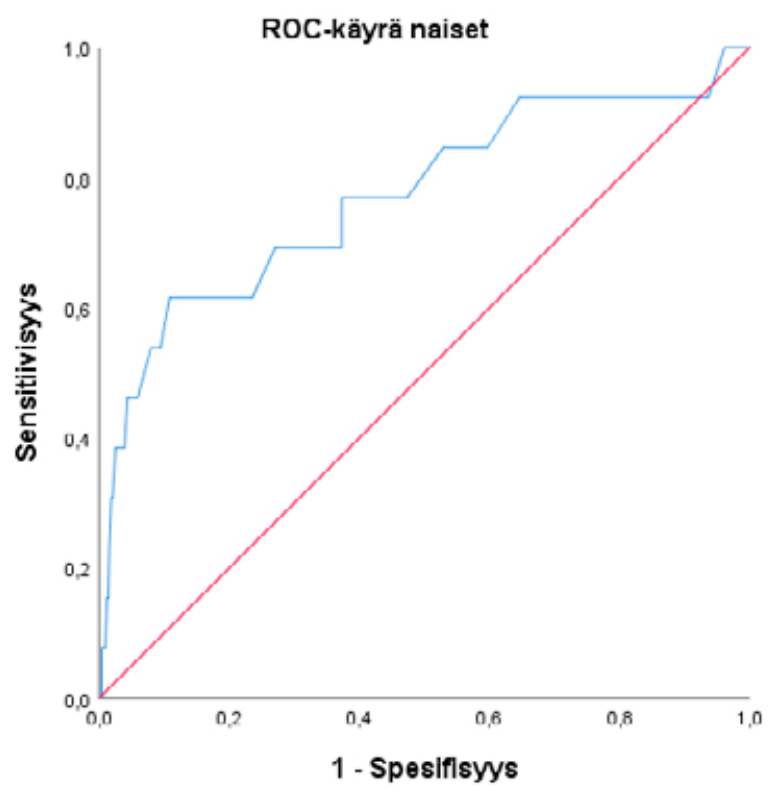

KUVIO 5. Autismikirjon osamäärän (AQ) kyky erotella (sensitiivisyys ja spesifisyys) autismikirjon naiset verrokkinaisista. 
TAULUKKO 3. Tietyn autismikirjon osamäärän (AQ) saavuttaneiden tai ylittäneiden koehenkilöiden prosenttiosuus.

\begin{tabular}{|c|c|c|c|c|}
\hline $\begin{array}{l}\text { AQ-pisteet } \\
(\max 50)\end{array}$ & $\begin{array}{l}\text { Autismikirjon } \\
\text { miehet (\%) } \\
\mathrm{n}=39\end{array}$ & $\begin{array}{l}\text { Autismikirjon } \\
\text { naiset }(\%) \\
n=13\end{array}$ & $\begin{array}{l}\text { Verrokki- } \\
\text { miehet (\%) } \\
n=567\end{array}$ & $\begin{array}{l}\text { Verrokki- } \\
\text { naiset (\%) } \\
n=1084\end{array}$ \\
\hline 0 & 100 & 100 & 100 & 100 \\
\hline 1 & 100 & 100 & 99,8 & 99,7 \\
\hline 2 & 100 & 100 & 99,8 & 99,2 \\
\hline 3 & 100 & 100 & 99,6 & 97,9 \\
\hline 4 & 100 & 100 & 98,6 & 96,2 \\
\hline 5 & 100 & 92,3 & 97 & 93,2 \\
\hline 6 & 100 & 92,3 & 94,2 & 89,3 \\
\hline 7 & 100 & 92,3 & 90,5 & 83,9 \\
\hline 8 & 97,2 & 92,3 & 84,5 & 78,8 \\
\hline 9 & 97,2 & 92,3 & 79,7 & 73 \\
\hline 10 & 97,2 & 92,3 & 74,4 & 65 \\
\hline 11 & 94,4 & 84,6 & 67,4 & 59,2 \\
\hline 12 & 88,9 & 84,6 & 60,3 & 53 \\
\hline 13 & 88,9 & 76,9 & 54 & 46,4 \\
\hline 14 & 86,1 & 76,9 & 48,5 & 37,3 \\
\hline 15 & 83,3 & 69,2 & 42 & 32,1 \\
\hline 16 & 83,3 & 69,2 & 37,6 & 27,2 \\
\hline 17 & 77,8 & 61,5 & 32,5 & 23,2 \\
\hline 18 & 75 & 61,5 & 28,4 & 19,6 \\
\hline 19 & 69,4 & 61,5 & 23,3 & 15,9 \\
\hline 20 & 61,1 & 61,5 & 20,1 & 13,1 \\
\hline 21 & 58,3 & 61,5 & 16,8 & 10,8 \\
\hline 22 & 52,8 & 53,8 & 13,8 & 9,2 \\
\hline 23 & 52,8 & 53,8 & 10,1 & 7,9 \\
\hline 24 & 50 & 46,2 & 8,6 & 5,8 \\
\hline 25 & 44,4 & 46,2 & 6,9 & 4,3 \\
\hline 26 & 38,9 & 38,5 & 4,8 & 3,9 \\
\hline 27 & 36,1 & 38,5 & 4,1 & 3 \\
\hline 28 & 33,3 & 38,5 & 2,6 & 2,5 \\
\hline 29 & 25 & 30,8 & 2,1 & 1,8 \\
\hline 30 & 19,4 & 23,1 & 1,4 & 1,6 \\
\hline 31 & 16,7 & 15,4 & 1,1 & 1,4 \\
\hline 32 & 11,1 & 15,4 & 0,9 & 1,2 \\
\hline 33 & 8,3 & 7,7 & 0,5 & 0,9 \\
\hline 34 & 8,3 & 7,7 & 0,5 & 0,6 \\
\hline 35 & 5,6 & 7,7 & 0,4 & 0,6 \\
\hline 36 & 5,6 & 7,7 & 0,4 & 0,5 \\
\hline 37 & 2,8 & 7,7 & 0,2 & 0,5 \\
\hline 38 & 2,8 & 7,7 & 0 & 0,4 \\
\hline 39 & 2,8 & 0 & 0 & 0,4 \\
\hline 40 & 0 & 0 & 0 & 0,3 \\
\hline 41 & 0 & 0 & 0 & 0,2 \\
\hline 42 & 0 & 0 & 0 & 0,1 \\
\hline 43 & 0 & 0 & 0 & 0 \\
\hline
\end{tabular}




\subsection{Osioanalyysi}

Autismikirjon ja verrokkiryhmien välisiä osiokohtaisia eroja tarkasteltaessa oli havaittavissa, että verrokkiryhmissä annetut vastaukset täyttivät pisteen kriteerit harvemmin kuin autismikirjon ryhmissä (ks. liite 1). Kun osioiden välisiä eroja tarkasteltiin Khiin neliötestillä, useissa osioissa erot nousivat tilastollisesti merkitseväksi, vaikka lukuisten testien tekemisen vuoksi tilastollisen merkitsevyyden ero olikin laskettu tasolle 0,001. Kaikissa osioissa, joissa havaittiin tilastollisesti merkitsevä ero, autismikirjon henkilöt arvioivat itseään niin, että he saivat useammin pisteen kuin heidän samaa sukupuolta edustavat verrokit (osassa kysymyksistä pisteen sai positiivisesta ja osassa negatiivisesta vastauksesta).

Ryhmien välisiä tilastollisesti merkitseviä eroja löydettiin autismikirjon miesten ja verrokkimiesten väliltä kuudessatoista osiossa. Näistä tilastollisesti merkitseviä eroja autismikirjon miesten ja verrokkimiesten välillä osoittaneista osioista seitsemän $(1,11,13$, $15,22,45$ ja 45) kuului sosiaalisten taitojen ja viisi $(27,31$, 33, 38 ja 39) kommunikaation osa-alueeseen. Lisäksi tilastollisesti merkitseviä eroja löytyi tarkkaavaisuuden siirtämisen osa-alueelta kahdesta (10 ja 32) ja yksityiskohtien huomioimisen osa-alueelta niin ikään kahdesta osiosta ( 5 ja 28). Tilastollisesti merkitseviä eroja osoittaneet osiot olivat:

1. Teen mieluummin asioita toisten kanssa kuin yksin $\left(X^{2}(1, N=615)=21,6\right.$, $p<0,001)$.

5. Huomaan usein heikkoja ääniä, joita muut eivät huomaa $\left(X^{2}(1, N=616)=\right.$ $14,4, p=0,001)$.

10. Sosiaalisessa ryhmässä ollessani pystyn helposti seuraamaan useiden ihmisten keskustelua $\left(X^{2}(1, N=613)=12,8\right.$, $p=0,001)$.
11. Minusta sosiaaliset tilanteet ovat help$\operatorname{poja}\left(X^{2}(1, N=614)=30,5, p<0,001\right)$.

13. Minulla on taipumus huomata yksityiskohtia, jotka jäävät muilta huomaamatta $\left(X^{2}(1, N=616)=51,9, p<0,001\right)$.

15. Tunnen suurempaa vetovoimaa ihmisiin kuin tavaroihin $\left(X^{2}(1, N=613)=\right.$ $13,7, p=0,001)$.

22. Minun on vaikea solmia uusia ystävyyssuhteita $\left(X^{2}(1, N=616)=17,2, p<\right.$ 0,001).

27. Minun on helppo "lukea rivien välistä", kun minulle puhutaan $\left(X^{2}(1, N=614)\right.$ $=36,1, p<0,001)$.

28. Keskityn yleensä enemmän kokonaisuuteen kuin pieniin yksityiskohtiin $\left(X^{2}(1\right.$, $N=613)=14,6, p<0,001)$.

31. Pystyn huomaamaan, jos minua kuunteleva henkilö pitkästyy $\left(X^{2}(1, N=\right.$ 615) $=18,4, p<0,001)$.

32. Minun on helppo tehdä useita asioita samanaikaisesti $\left(X^{2}(1, N=613)=11,4, p\right.$ $=0,001)$.

33. Kun puhun puhelimessa, en ole varma, milloin on minun vuoroni puhua $\left(X^{2}(1, N=616)=22,3, p<0,001\right)$.

38. Olen hyvä sosiaalinen jutustelija $\left(X^{2}(1, N=615)=31,0, p<0,001\right)$.

39. Minulle sanotaan usein, että jatkan samasta aiheesta loputtomiin $\left(X^{2}(1, N=\right.$ 616) $=17,0, p<0,001)$.

45. Minun on vaikea päätellä toisten aiko$\operatorname{muksia}\left(X^{2}(1, N=612)=23,6, p<0,001\right)$.

47. Nautin uusien ihmisten kohtaamisesta $\left(X^{2}(1, N=610)=23,6, p<0,001\right)$. 
Verrattaessa autismikirjon naisia ja verrokkinaisia havaittiin tilastollisesti merkitseviä ryhmäeroja viidessä osiossa. Näistä viidestä osiosta kaksi (36 ja 45) kuului sosiaalisten taitojen, kaksi (27 ja 33) kommunikaation ja yksi (41) mielikuvituksen osa-alueeseen:

27. Minun on helppo "lukea rivien välistä", kun minulle puhutaan $\left(X^{2}(1, N=\right.$ $1118)=21,8, p=0,001)$.

33. Kun puhun puhelimessa, en ole varma, milloin on minun vuoroni puhua $\left(X^{2}(1, N=616)=22,3, p<0,001\right)$.

36. Minun on helppo ajatella pelkästään toisen kasvoja katsomalla, mitä hän ajattelee tai tuntee $\left(X^{2}(1, N=1118)=14,8\right.$, $p<0,001)$.

41. Kerään mielelläni tietoa asioiden luokista (esimerkiksi automerkeistä, lintulajeista, junalajeista, kasvilajeista jne.) $\left(X^{2}(1, N=1118)=21,3, p=0,001\right)$.

45. Minun on vaikea päätellä toisten aikomuksia $\left(X^{2}(1, N=1117)=34,2, p<\right.$ 0,001).

\subsection{Autismikirjon osamäärän (AQ) reliabiliteetti}

Kun kaikki osiot ja koko aineisto huomioitiin AQ:n Cronbachin alfa-kertoimeksi saatiin 0,818 , joten testin sisäinen reliabiliteetti voidaan arvioida hyväksi. Tarkasteltaessa alfa-kertoimia osa-alueittain hyvään reliabiliteettiin ylsivät sosiaaliset taidot $(\alpha=0,746)$, kommunikaatio $(\alpha=0,676)$, yksityiskohtien huomioiminen $(\alpha=0,615)$ ja tarkkaavaisuuden siirtäminen $(\alpha=0,600)$, kun taas mielikuvitusta mittaavan osa-alueen alfa-kerroin jäi muita osa-alueita alhaisemmaksi $(\alpha=0,492)$.

\section{POHDINTA}

Tämän tutkimuksen tavoitteena oli selvittää AQ:n toimivuutta suomalaisväestössä ja samalla tutkia autismikirjon piirteitä nuorilla aikuisilla. Tutkimus antaa tärkeää perustietoa siitä, miten nuoret aikuiset, joilla on autismikirjon häiriö, ja heidän verrokkinsa arvioivat itseään autismikirjon piirteiden osalta. AQ ei keskity vain yhteen osa-alueeseen, vaan sen avulla pystytään kartoittamaan henkilön näkemys autismikirjon ydinpiirteistön sopivuudesta omaan persoonaan nopeasti ja kustannustehokkaasti sosiaalisten taitojen, kommunikaation, mielikuvituksen, tarkkaavuuden siirtämisen ja yksityiskohtien huomioimisen osalta.

Autismikirjon henkilöt saivat AQ:sta verrokkeja merkitsevästi korkeampia kokonaispistemääriä, joten suomalaisten autismikirjon henkilöiden tulokset olivat sikäli linjassa aikaisempien tutkimusten kanssa (mm. BaronCohen ym., 2001; Lundqvist \& Lindner, 2017; Woodbury-Smith, Robinson, Wheelwright \& Baron-Cohen, 2005). Katsottaessa tarkemmin pistemääriä tämän suomalaistutkimuksen ja muualla tehtyjen aikaisempien tutkimusten välillä on kuitenkin myös eroja nähtävissä. Tutkimukseemme osallistuneet henkilöt saivat kauttaaltaan matalampia pisteitä kuin esimerkiksi Baron-Cohenin ja hänen työryhmänsä (2001) tutkimuksen osallistujat. Näin ollen suomalaiset autismikirjon naiset ja miehet sekä verrokkinaiset ja -miehet pisteyttivät itselleen vähemmän autismikirjon piirteitä kuin vastaavat englantilaiset ryhmät.

AQ:n erottelukyky autismikirjon miesten ja verrokkien välillä ylsi melko hyvään mutta jäi naisten osalta kohtalaiseksi. Tämän tutkimuksen miesten AQ:n ROC-käyrän muoto ja arvot (mittarin sensitiivisyys ja spesifisyys) vastaavat jotakuinkin Lundqvistin ja Lindnerin (2017) Ruotsissa keräämän aineiston 
ROC-käyrän muotoa ja arvoja. Tuloksia vertailtaessa on kuitenkin huomioitava, että Lunqvistin ja Lindnerin tutkimuksessa ei ollut eroteltu naisten ja miesten aineistoja toisistaan. Tämän tutkimuksen ROC-käyristä ei pystytty määrittämään selkeitä katkaisurajoja, vaan voitiin ainoastaan antaa mahdollisia rajavaihtoehtoja, joita tutkijat ja muut autismikirjon parissa työskentelevät asiantuntijat voivat hyödyntää harkiten. Mikäli testin sensitiivisyyttä halutaan nostaa lähelle $80 \%$ :n rajaa, spesifisyys laskee huomattavan alhaiseksi erityisesti naisilla. Siksi nyt määritellyissä naisten katkaisurajoissa sensitiivisyys jää $77 \%$ :iin, mikä on syytä ottaa huomioon käytettäessä AQ:ta autismikirjon piirteiden seulontavälineenä. Joka tapauksessa huomattavaa on, että suomalaisten miesten ja naisten katkaisupisteet jäivät aikaisempia tutkimuksia selvästi matalammiksi. Baron-Cohen ja hänen työryhmänsä (2001) ovat omassa tutkimuksessaan määritelleet AQ-lomakkeen katkaisupisteeksi 32, jonka heidän tutkimuksessaan ylitti $80 \%$ autismikirjon henkilöistä, mutta saman pistemäärän ylittäneitä verrokkihenkilöitä oli vain $2 \%$. Woodbury-Smith ja tutkimusryhmä (2005) ehdottivat puolestaan katkaisupisteeksi 26, joka heidän tutkimuksessaan antoi $83 \%$ :n sensitiivisyyden. Tässä tutkimuksessa tulososiossa esitetyt katkaisupisteet vaihtelivat miehillä 15 ja 18 pisteen välillä ja naisilla 13 ja 16 pisteen välillä. Nämä luvut suhteutuvat myös verrokkiryhmän ja autismikirjon ryhmien keskiarvoihin ja keskihajontoihin sekä prosenttijakaumiin. Jatkossa kannattaisi tarkastella, voisiko AQ:n suomalaisen version sensitiivisyys ja spesifisyys nousta, mikäli käyttäisimme siitä lyhennettyä versiota (ks. esim. Booth ym., 2013), sillä osa $A Q$ :n väittämistä voi jopa laskea mittarin erottelukykyä (Agelink van Rentergem, Lever \& Geurts, 2019).

Tarkasteltaessa yksittäisen henkilön mahdollisia autismikirjon piirteitä on hyvä muis- taa, että katkaisupiste toimii vain suuntaa antavana arvona. Lisäksi kannattaa katsoa pistemääriä suhteessa verrokkien keskiarvoon ja keskihajontaan, pisteiden jakautumista eri osa-alueiden ja osioiden kesken sekä verrata pisteiden jakautumista verrokkien pisteiden jakautumiseen. Pisteiden jakautuminen eri osa-alueille antaa tärkeää tietoa siitä, painottuuko henkilön kokemissa vaikeuksissa jokin tietty osa-alue, kuten kommunikaatio. Tällainen tarkempi tarkastelu voi antaa myös lisätietoa siitä, millaisia jatkotutkimuksia kannattaa tehdä. Lisäksi pisteiden tarkastelussa on tärkeä muistaa, että $A Q$ on vain yksi seulontamenetelmä ja henkilön vastauksiin on voinut vaikuttaa esimerkiksi hänen itsetuntemuksensa puute tai halu tarjota tietyntyyppisiä sosiaalisesti sopivaksi opittuja vastauksia. Lisäksi autismikirjon häiriön kanssa samanlaisia piirteitä voi esiintyä myös muissa häiriöissä (South ym., 2017), mikä voi näkyä kohonneina pisteinä.

Ero suomalaisten ja englantilaisten koehenkilöiden tulosten välillä osoittaa sen (BaronCohen ym., 2001; Woodbury-Smith ym., 2005), miten tärkeää on saada suomalaiset viitearvot mittareille, ennen kuin niitä aletaan käyttää laaja-alaisemmin ja pohtia mahdollisia katkaisupistemääriä ja mittarin toimivuutta suomalaisesta aineistosta käsin. Samansuuntainen linjaus on näkynyt myös muissa käännetyissä mittareissa, esimerkiksi Lasten kommunikaation kyselyssä-2 (Children's Communication Checklist-2, CCC-2, Bishop, 2015) suomalaiset viitearvot ovat erilaiset kuin englantilaisten ja australialaisten lasten viitearvot. Nykytietämyksen valossa on ilmeistä, että kulttuurilla on merkittävä vaikutus ainakin sosiaaliseen kommunikaatioon (esim. Gabbatore ym., 2019; Jokinen \& Wilcock, 2006). Esimerkiksi lievillä eleiden käytön vaikeuksilla ja muilla nonverbaalisilla haasteilla sekä lievästi puutteellisilla sosiaali- 
sen jutustelun taidoilla ei luultavasti ole yhtä suurta merkitystä suomalaisessa kulttuurissa kuin monissa Etelä- ja Keski-Euroopan kulttuureissa. Tästä johtuen kyseisillä osa-alueilla esiintyvät lievät vaikeudet eivät välttämättä tule esille tai eivät aiheuta haittaa suomalaisessa kulttuurissa, vaan voivat mennä suomalaisille tyypillisen sosiaalisen kommunikaation piiriin. On myös mahdollista, että suomalaiset koehenkilöt ovat pisteyttäneet itseään myönteisemmin kuin aikaisempien tutkimusten koehenkilöt. Sallinen-Kuparinen, McCroskey ja Richmond (1991) ovat nimittäin havainneet, että suomalaiset arvioivat kykynsä kommunikoida eri tilanteissa samalle tasolle amerikkalaisten henkilöiden kanssa, vaikka todellisuudessa he olisivat olleet pidättyväisempiä ja haluttomampia kommunikoimaan kuin amerikkalaiset henkilöt. Jatkossa olisi myös mielenkiintoista vertailla eri kieli- ja kulttuuriympäristöjen kesken sitä, erottelevatko samat osiot herkimmin autismikirjon ryhmän verrokeista. Näin saataisiin enemmän tietoa universaaleista ja mahdollisista kulttuuri- ja kieliympäristösidonnaisista piirteistä.

Katsottaessa yksittäisten osioiden pisteitä oli huomattavaa, että tässä tutkimuksessa autismikirjon miehet erosivat useammissa osioissa tilastollisesti merkitsevästi verrokkimiehistä (16 osiota) kuin autismikirjon naiset verrokkinaisista ( 5 osiota). Näissä kaikissa osioissa autismikirjon ryhmät olivat pisteyttäneet itselleen korkeammat pisteet kuin heidän sukupuolensa mukaiset verrokkinsa. Näistä osioista selvä enemmistö kuului sosiaalisten taitojen ja kommunikaation osaalueille. Sekä miesten että naisten ryhmissä eroja aiheuttivat pragmaattista ymmärtämistä kuvaava osio Minun on belppo "lukea rivien välistä, kun minulle pubutaan, kommunikaatiossa keskeisenä olevaa vuorottelua kuvaava Kun pubun pubelimessa, en ole varma, milloin on minun vuoroni pubua sekä mielen teori- aan liittyvä Minun on vaikea päätellä toisten aikomuksia. Nämä kaikki osiot kuvastavat osatekijöitä, joissa esiintyvien haasteiden voi helposti ajatella aiheuttavan nuorelle aikuiselle huomattavaa haittaa arjen moninaisissa sosiaalisen kommunikaation tilanteissa, ja niissä esiintyvät vaikeudet onkin tunnistettu useissa tutkimuksissa autismikirjon piirteiksi, joissa ilmenevät vaikeudet näkyvät vielä aikuisiässä (Heavey Phillips, Baron-Cohen \& Rutter, 2000; Lönnqvist ym., 2017; ks. myös Loukusa \& Moilanen, 2009).

AQ:n reliabiliteettia arvioitaessa havaittiin, että mielikuvitusta mittaavan osa-alueen alfakerroin jäi muita osa-alueita alhaisemmaksi. Jatkossa olisikin syytä tarkastella mielikuvitusta mittaavan osa-alueen osioita syvällisemmin, jotta heikon reliabiliteetin syyt nousisivat esille. Lisäksi jatkossa olisi mielenkiintoista vertailla, onko AQ:n eri osa-alueiden reliabiliteetti samansuuntainen eri kieli- ja kulttuuriympäristöistä tulevissa tutkimuksissa.

Tämän tutkimuksen vahvuutena voidaan pitää huomattavan suuria nuorten miesten ja naisten verrokkiryhmiä, joiden avulla oli mahdollista saada varsin luotettava kuva suomalaisten henkilöiden tyypillisistä AQpistemääristä. Vaikka tässä tutkimuksessa autismikirjon miehet olivat keskimäärin hieman vanhempia kuin muiden ryhmien henkilöt, kaikkien osallistujien voidaan ajatella olevan nuoria aikuisia ja elävän suunnilleen samaa ikävaihetta. AQ on tarkoitettu älykkyydeltään tyypillisellä tasolla (tai sen yli) toimiville henkilöille, ja niinpä myös tässä tutkimuksessa osallistujien joukosta oli karsittu henkilöt, joilla oli älyllinen kehitysvamma. Kuten muissakin kyselylomakkeissa, myös AQ:ssa on omat heikkoutensa, ja pisteen saamiseen voi vaikuttaa muun muassa henkilön temperamentti (esim. osio 13 "Menen mieluummin kirjastoon kuin juhliin.”), itsetuntemus ja muu psykiatrinen oireisto. Lisäksi 
pisteiden skaalauksella voi olla vaikutuksensa: osiosta saa pisteen riippumatta siitä, vastaako lievästi vai vahvasti poikkeavasti. Vaikka AQ:n erottelukyky ei ole paras mahdollinen, tämän tutkimuksen pohjalta sen voi ajatella toimivan suuntaa antavana, yhtenä nopeasti toteutettavana autismikirjon piirteiden tunnistamisen seulontamenetelmänä suomalaisväestössä. Tärkeää on kuitenkin huomioida, että AQ ei tunnista kaikkia autismikirjon henkilöitä ja vastaavasti pisteet voivat kohota myös tyypillistä aikuisväestöä edustavilla henkilöillä. Näin ollen AQ:n tulosta tulee tulkita tilanteesta käsin harkiten, jotta varmistetaan, että autismikirjon henkilö ei mene seulasta lävitse ja jää ilman tarvitsemiaan tarkempia tutkimuksia ja mahdollista kuntoutusta ja muuta tukea.

\section{KIITOKSET}

Lämmin kiitos kaikille tutkimukseen osallistuneille nuorille aikuisille. Kiitos psykologian opiskelija Laura Mämmelälle avusta aineiston tallentamisessa sekä Oulun autismikirjon tutkijoille tuesta ja mielenkiintoisista keskusteluista tämän tutkimuksen aihepiiriin liittyen. Kiitos myös LL Ulrika Roineelle vastauksista $\mathrm{AQ}$ :n käännösprosessiin liittyviin kysymyksiin. Tätä tutkimusta ovat rahoittaneet Aivosäätiö, Stiftelsen Alma och K. A. Snellman Säätiö ja Suomen Akatemia.

\section{LÄHTEET}

Agelink van Rentergem, J. A., Lever, A. G., \& Geurts, H. M. (2019). Negatively phrased items of the Autism Spectrum Quotient function differently for groups with and without autism. Autism, 23, 1752-1764.

American Psychiatric Association. (2013). Diagnostic and statistical manual of mental disorders. Fifth edition. Washington, DC: Author.

Baron-Cohen, S. (2009). Autism: The Empathizing-Systemizing (E-S) Theory. The Year in Cognitive Neuroscience, 68-80.

Baron-Cohen, S., Hoekstra, R. A., Knickmeyer, R. \& Wheelwright, S. (2006). The autismspectrum quotient (AQ)-adolescent version. Journal of Autism and Developmental Disorders, 36, 1230-1240.

Baron-Cohen, S., Leslie, A. M. \& Frith, U. (1985). Does the autistic child have a "theory of mind"? Cognition, 21, 37-46.

Baron-Cohen, S., Richler, J., Bisarya, D., Gurunathan, N. \& Wheelwright, S. (2003). The Systemising Quotient (SQ): An investigation of adults with Asperger Syndrome or High Functioning Autism and normal sex differences. Philosophical Transactions of the Royal Society, Series B, Special issue on Autism. Mind and Brain, 358, 361-374.

Baron-Cohen, S. \& Wheelwright, S. (2004). The Empathy Quotient (EQ). An investigation of adults with Asperger Syndrome or High Functioning Autism, and normal sex differences. Journal of Autism and Developmental Disorders, 34, 163-175.

Baron-Cohen, S., Wheelwright, S., Skinner, R., Martin, J. \& Clubley, E. (2001). The Autism Spectrum Quotient (AQ): Evidence from Asperger syndrome/high functioning autism, males and females, scientists and mathematicians. Journal of Autism and Developmental Disorders, 31, 5-17.

Bishop, D.V.M. (2015). Lasten kommunikointitaitojen kysely, toinen painos (Yliherva, A., Loukusa, S. \& Väisänen, R, käänt.), Helsinki: Hogrefe Psykologien Kustannus Oy. (Alkuperäinen teos The Children's Communication Checklist-2, CCC-2, julkaistu 2003). 
Bishop, S. L., Hus, V., Duncan, A., Huerta, M., Gotham, K., Pickles, A., ... Lord, C. (2013). Subcategories of restricted and repetitive behaviors in children with autism spectrum disorders. Journal of Autism and Developmental Disorders, 43, 1287-1297

Booth, T., Murray, A. L., McKenzie, K., Kuenssberg, R., O’Donnell, M. \& Burnett H. (2013). Brief report: an evaluation of the AQ10 as a brief screening instrument for ASD in adults. Journal of Autism and Developmental Disorders, 43, 2997-3000.

Deliens, G., Papastamou, F., Ruytenbeek, N., Geelhand de Merxem, P. \& Kissine, M. (2018). Selective pragmatic impairment in autism spectrum disorder: Indirect requests vs irony. Journal of Autism and Developmental Disorders, 48, 2938-2952.

Developmental Disabilities Monitoring Network Surveillance Year 2010 Principal Investigators and Centers for Disease Control and Prevention (CDC) (2014). Prevalence of autism spectrum disorder among children aged 8 years - Autism and developmental disabilities monitoring network, 11 sites, United States, 2010. Morbidity and Mortality Weekly Report. Surveillance Summaries, 63, 1-21.

Ehlers, S., Gillberg, C., \& Wing, L. (1999). A screening questionnaire for Asperger syndrome and other high-functioning autism spectrum disorders in school age children. Journal of Autism and Developmental Disorders, 29, 129141.

El Khouli, R. H., Macura, K. J., Barker, P. B., Phil, D., Habba, M. R., Jacobs, M. A. \& Bluemke, D. A. (2009). The relationship of temporal resolution to diagnostic performance fordynamic contrast enhanced (DCE) MRI of the Breast. Journal of Magnetic Resonance Imaging: JMRI, 30, 999-1004.

Emerich, D. M., Creaghead, N. A., Grether, S. M., Murray, D., \& Grasha, C. (2003). The comprehension of humorous materials by adolescents with high-functioning autism and Asperger's syndrome. Journal of Autism and Developmental Disorders, 33, 253-257.

Forsström, J. (1995). Testien diagnostisen arvon mittaaminen ROC-käyrän avulla. Lääketieteellinen Aikakauskirja Duodecim, 111, 237-245.
Frith, U. (1989). Autism: Explaining the Enigma. Oxford, UK: Blackwell Publishing.

Gabbatore, I., Bosco, F. M., Mäkinen, L., Ebeling, H., Hurtig, T., \& Loukusa, S. (2019). Investigating pragmatic abilities in young Finnish adults using the Assessment Battery for Communication. Intercultural Pragmatics, 16, 27-56.

Guo, Y. Q., Tang, Y., Rice, C., Lee, L. C., Wang, Y. F., \& Cubells, J. F. (2011). Validation of the Autism Spectrum Screening Questionnaire, Mandarin Chinese Version (CH-ASSQ) in Beijing, China. Autism, 15, 713-727.

Heavey, L., Phillips, W., Baron-Cohen, S. \& Rutter, M. (2000). The awkward moments test: A naturalistic measure of social understanding in autism. Journal of Autism and Developmental Disorders, 30, 225-236.

Hill, E. L. (2004). Executive dysfunction in autism. Trends in Cognitive Sciences, 8, 26-32.

Hoekstra, R. A., Bartels, M., Cath, D. C. \& Boomsma, D. I. (2008). Factor structure, reliability and criterion validity of the AutismSpectrum Quotient (AQ): A study in Dutch population and patient groups. Journal of Autism and Developmental Disorders, 38, 1555-1566.

Huttunen, K. \& Pine, K. (2012). Communication culture and gesture use. In J. Toyota, P. Hallonsten, \& M. Shchepetunina (toim.), Sense of emptiness: An interdisciplinary approach (s. 94-111). Newcastle Upon Tyne, UK: Cambridge Scholars Publishing.

Jokinen, K. \& Wilcock, G. (2006). Contextual inferences in intercultural communication. SKY Journal of Linguistics, 19, 291-300.

Jussila, K., Junttila, M., Kielinen, M., Ebeling, H., Joskitt, L., Moilanen, I. \& Mattila, M-L. (2019). Sensory abnormality and quantitative autism traits in children with and without autism spectrum disorder in an epidemiological population. Journal of Autism and Developmental Disorders. DOI: 10.1007/ s10803-019-04237-0.

Ketelaars, C., Horwitz, E., Sytema, S., Bos, J., Wiersma, D., Minderaa, R. \& Hartman, C. A. (2008). Brief report: Adults with mild Autism Spectrum Disorders (ASD): Scores on the AutismSpectrum Quotient (AQ) and comorbid psychopathology. Journal of Autism and Developmental Disorders, 38, 176-180. 
Kuusikko, S., Haapsamo, H., Jansson-Verkasalo, E., Hurtig, T., Mattila M.-L., Ebeling, H., Jussila, K., Bölte, S. \& Moilanen, I. (2009). Emotion recognition in children and adolescents with autism spectrum disorders. Journal of Autism and Developmental Disorders, 39, 938-945.

Lam, K., Bodfish, J. \& Piven, J. (2008). Evidence for three subtypes of repetitive behavior in autism that differ in familiarity and association with other symptoms. Journal of Child Psychology and Psychiatry, 49, 1193-1200.

Loukusa, S. (painossa). Autism spectrum disorder. In L. Cummings (Ed.), Pragmatic Language Disorders: Complex and Underserved Populations. Springer.

Loukusa, S., Leinonen, E., Jussila, K., Mattila, M.-L., Ryder, N., Ebeling, H. \& Moilanen, I. (2007). Answering contextually demanding questions: Pragmatic errors produced by children with Asperger syndrome or highfunctioning autism. Journal of Communication Disorders, 40, 357-381.

Loukusa, S. \& Moilanen, I. (2009). Pragmatic inference abilities in individuals with Asperger syndrome or high-functioning autism. A review. Research in Autism Spectrum Disorders, 3, 890904.

Loukusa, S., Mäkinen, L., Kuusikko-Gauffin, S., Ebeling, H., \& Moilanen, I. (2014). Theory of mind and emotion recognition skills in children with specific language impairment, autism spectrum disorder and typical development: Group differences and connection to knowledge of grammatical morphology, word-finding abilities and verbal working memory. International Journal of Language \& Communication Disorders, 49, 498-507.

Lundqvist, L. O. \& Lindner, H. I. (2017). Is the Autism-Spectrum Quotient a Valid Measure of Traits Associated with the Autism Spectrum? A Rasch Validation in Adults with and Without Autism Spectrum Disorders. Journal of Autism and Developmental Disorders, 47, 2080-2091.

Lüdemann, L., Grieger, W., Wurm, R., Wust, P., \& Zimmer, C. (2005). Glioma assessment using quantitative blood volume maps generated by $\mathrm{T} 1$-weighted dynamiccontrast-enhanced magnetic resonance imaging: A receiver operating characteristic study. Acta Radiologica, 47, 303-310.
Lönnqvist, L., Loukusa, S., Hurtig, T., Mäkinen, L., Siipo, A., Väyrynen, E., ... Ebeling, H. (2017). How young adults with autism spectrum disorder watch and interpret pragmatically complex scenes. Quarterly Journal of Experimental Psychology, 70, 2331-2346.

Mattila, M. L., Jussila, K., Linna, S. L., Kielinen, M., Bloigu, R., Kuusikko-Gauffin, S., ... Moilanen, I. (2012). Validation of the Finnish Autism Spectrum Screening Questionnaire (ASSQ) for clinical settings and total population screening. Journal of Autism and Developmental Disorders, 42, 2162-2180.

Mattila, M. L., Kielinen, M., Linna, S. L., Jussila, K., Ebeling, H., Bloigu, R., Joseph, R. M., \& Moilanen, I. (2011). Autism spectrum disorders according to DSM-IV-TR and comparison with DSM-5 draft criteria: an epidemiological study. Journal of the American Academy Child and Adolescent Psychiatry, 50, 583-592.

Metsämuuronen, J. (2006). Metodologian perusteet ihmistieteissä. Teoksessa J. Metsämuuronen (toim.), Laadullisen tutkimuksen käsikirja (s. 16-77). Helsinki: International Methelp.

Mäkinen, L., Gabbatore, I., Loukusa, S., Kunnari, S. \& Schneider, P. (2019). A Comparison of Picture-based Narratives by Finnish, Italian and English-speaking Children. Early Education and Development. DOI: 10.1080/10409289.2019.1666446.

Paul, R., Orlovski, S. M., Marcinko, H. C. \& Volkmar, F. (2009). Conversational behaviors in youth with high-functioning ASD and Asperger syndrome. Journal of Autism and Developmental Disorders, 39, 115-125.

Posserud, M. B., Lundervold, A. J., \& Gillberg, C. (2009). Validation of the autism spectrum screening questionnaire in a total population sample. Journal of Autism and Developmental Disorders, 39, 126-134.

Postorino, V., Fatta, L. M., Sanges, V., Giovagnoli, G., De Peppo, L., Vicari, S. \& Mazzone, L. (2016). Intellectual disability in autism spectrum disorder: Investigation of prevalence in an Italian sample of children and adolescents. Research in Developmental Disabilities, 48, 193-201. 
Robertson, C.E., \& Baron-Cohen, S. (2017). Sensory perception in autism. Nature Reviews Neuroscience, 18, 671-684.

Roine, U., Roine, T., Salmi, J., Nieminen-Von Wendt, T., Leppämäki, S., Rintahaka, P., Tani, P., Leemans, A. \& Sams, M. (2013). Increased coherence of white matter fiber tract organization in adults with Asperger syndrome: A diffusion tensor imaging study. Autism Research, 6, 642-650.

Sallinen-Kuparinen, A., McCroskey, J. C. \& Richmond, V. P. (1991). Willingness to communicate, communication apprehension, introversion, and self-reported communication competence: Finnish and American comparisons. Communication Research Reports, 8, 55-64.

Sng, C. Y., Carter, M. \& Stephenson, J.A. (2018). A systematic review of the comparative pragmatic differences in conversational skills of individuals with autism. Autism \& Developmental Language Impairments, 3, 1-24.

South, M., Carr, A. W., Stephenson, K. G., Maisel, M. E. \& Cox, J. C. (2017). Symptom overlap on the SRS-2 adult self-report between adults with ASD and adults with high anxiety. Autism Research, 10, 1215-1220.

Tager-Flusberg, H. \& Kasari, C. (2013). Minimally verbal school-aged children with autism spectrum disorder: The neglected end of the spectrum. Autism Research, 6, 468-478.

Wang, A. T., Lee, S. S., Sigman, M. \& Dapretto, M. (2006). Neural basis of irony comprehension in children with autism: The role of prosody and context. Brain, 129, 932-943.

Woodbury-Smith, M. R., Robinson, J., Wheelwright, S. \& Baron-Cohen, S. (2005). Screening adults for Asperger syndrome using the AQ: a preliminary study of its diagnostic validity in clinical practice. Journal of Autism and Developmental Disorders, 35, 331-335.

World Health Organization (2018). International statistical classification of diseases and related health problems. 11th Revision (ICD-11). Haettu 25.8.2019 osoitteesta https://icd.who. int/browse11/1-m/en. 
LIITE 1.

Osioanalyysi: Pisteen saaneiden prosenttiosuus ryhmän sisällä

\begin{tabular}{|c|c|c|c|c|}
\hline Osio & $\begin{array}{l}\text { Autismikirjon } \\
\text { miehet (\%) }\end{array}$ & $\begin{array}{l}\text { Autismikirjon } \\
\text { naiset (\%) }\end{array}$ & $\begin{array}{l}\text { Verrokki-miehet } \\
(\%)\end{array}$ & $\begin{array}{l}\text { Verrokki-naiset } \\
(\%)\end{array}$ \\
\hline 1 & 59 & 54 & 25 & 19 \\
\hline 2 & 55 & 38 & 70 & 71 \\
\hline 3 & 13 & 23 & 8 & 8 \\
\hline 4 & 72 & 69 & 48 & 40 \\
\hline 5 & 49 & 31 & 22 & 22 \\
\hline 6 & 36 & 31 & 45 & 40 \\
\hline 7 & 26 & 31 & 13 & 7 \\
\hline 8 & 18 & 23 & 21 & 12 \\
\hline 9 & 24 & 23 & 10 & 16 \\
\hline 10 & 38 & 23 & 16 & 13 \\
\hline 11 & 67 & 54 & 26 & 25 \\
\hline 12 & 79 & 62 & 61 & 58 \\
\hline 13 & 62 & 38 & 15 & 17 \\
\hline 14 & 54 & 46 & 47 & 49 \\
\hline 15 & 43 & 23 & 18 & 9 \\
\hline 16 & 56 & 62 & 34 & 26 \\
\hline 17 & 33 & 23 & 19 & 12 \\
\hline 18 & 33 & 46 & 17 & 19 \\
\hline 19 & 27 & 46 & 44 & 17 \\
\hline 20 & 18 & 23 & 9 & 6 \\
\hline 21 & 55 & 38 & 36 & 31 \\
\hline 22 & 48 & 46 & 34 & 32 \\
\hline 23 & 54 & 38 & 42 & 27 \\
\hline 24 & 64 & 46 & 43 & 23 \\
\hline 25 & 33 & 23 & 17 & 22 \\
\hline 26 & 61 & 54 & 41 & 31 \\
\hline 27 & 51 & 46 & 14 & 8 \\
\hline 28 & 51 & 54 & 24 & 28 \\
\hline 29 & 18 & 39 & 33 & 15 \\
\hline 30 & 51 & 46 & 57 & 77 \\
\hline 31 & 28 & 31 & 7 & 6 \\
\hline 32 & 31 & 54 & 57 & 16 \\
\hline 33 & 33 & 54 & 9 & 9 \\
\hline 34 & 26 & 15 & 20 & 17 \\
\hline 35 & 56 & 23 & 25 & 20 \\
\hline 36 & 57 & 41 & 25 & 21 \\
\hline 37 & 38 & 54 & 19 & 21 \\
\hline 38 & 47 & 69 & 34 & 28 \\
\hline 39 & 44 & 46 & 17 & 16 \\
\hline 40 & 23 & 15 & 29 & 22 \\
\hline 41 & 56 & 62 & 42 & 15 \\
\hline 42 & 51 & 62 & 39 & 37 \\
\hline 43 & 47 & 62 & 47 & 42 \\
\hline 44 & 39 & 38 & 17 & 14 \\
\hline 45 & 59 & 85 & 24 & 19 \\
\hline 46 & 56 & 69 & 36 & 44 \\
\hline 47 & 54 & 46 & 22 & 22 \\
\hline 48 & 62 & 85 & 36 & 43 \\
\hline 49 & 33 & 31 & 38 & 62 \\
\hline 50 & 49 & 69 & 40 & 34 \\
\hline
\end{tabular}




\section{AUTISM SPECTRUM QUOTIENT (AQ) IN SCREENING FEATURES OF AUTISM SPECTRUM: DISCRIMINATORY ABILITY OF SCREENING FORM IN YOUNG ADULTS}

Soile Loukusa, Research Unit of Logopedics, University of Oulu

Aija Kotila, Research Unit of Logopedics, University of Oulu

Marja-Leena Mattila, PEDEGO Research Unit, Faculty of Medicine, University of Oulu and

Clinic of Child Psychiatry, Oulu University Hospital

Maija Ylämäki, South Karelia Social and Health Care District (Eksote)

Leena Joskitt, Clinic of Child Psychiatry, Oulu University Hospital and

PEDEGO Research Unit, University of Oulu

Irma Moilanen, Clinic of Child Psychiatry, Oulu University Hospital and

PEDEGO Research Unit, University of Oulu

Hanna Ebeling, PEDEGO Research Unit, Faculty of Medicine, University of Oulu and

Clinic of Child Psychiatry, Oulu University Hospital

Tuula Hurtig, Research Unit of Clinical Neuroscience, PEDEGO Research Unit,

University of Oulu and Clinic of Child Psychiatry, Oulu University Hospital

Features of autism spectrum include areas of social skills, communication, imagination, attention switching and attention to details. These features can be screened with Autism Spectrum Quotient (AQ). The purpose of this study is to obtain Finnish performance values for $A Q$ and to study whether the AQ discriminates Finnish young adults on the autism spectrum from same-gender controls without autism spectrum diagnosis. In addition, differences between groups in each item and internal consistency of AQ has been studied. A total of 52 young adults on the autism spectrum ( 39 males and 13 females) and 1686 controls ( 577 males and 1109 females) took part in this study. Results show that individuals on the autism spectrum have higher scores than same-gender controls. AQ discriminates quite well males on the autism spectrum from control males but only fairly females on the autism spectrum from control females. In item analysis most statistically significant differences between groups were found in items measuring social skills and communication.

Keywords: attention to details, attention switching, autism spectrum, AQ, communication, screening, social skills 